\title{
EARLY STUNTING DETECTION EDUCATION AS AN EFFORT TO INCREASE MOTHER'S KNOWLEDGE ABOUT STUNTING PREVENTION
}

\author{
Gadis Meinar Sari ${ }^{1 *}$, Amrina Rosyada $^{2}$, Allyra Himawati ${ }^{3}$, Dinda Rahmaniar ${ }^{2}$, Priyo Budi Purwono ${ }^{4}$ \\ ${ }^{1}$ Department of Physiology, Faculty of Medicine, Universitas Airlangga, Surabaya, Indonesia, ${ }^{2}$ Ksatria Airlangga \\ Hospital Ship, Faculty of Medicine, Universitas Airlangga, Surabaya, Indonesia, ${ }^{3}$ Faculty of Public Health, \\ Universitas Airlangga, Surabaya, Indonesia, ${ }^{4}$ Department of Microbiology, Faculty of Science, Mahidol \\ University, Bangkok, Thailand
}

\section{ABSTRACT}

Stunting is one of the main nutritional problems that is still common in children under five and has serious health impacts. The results of National Health Research (Riskesdas) in 2018 showed the prevalence of stunting at 30.8\%, indicating that 1 out of 3 Indonesian children are still stunted. Probolinggo Regency is a priority area for stunting handling in 2019 with a prevalence of $50.2 \%$ according to a report from the National Team for the Acceleration of Poverty Reduction (TNP2K). One of the factors that directly affect the incidence of stunting is low birth weight (LBW), while the mothers' knowledge level of health is an indirect factor that affects the growth conditions of children under five. The purpose of this study was to analyze the effect of providing stunting early detection education on maternal knowledge regarding stunting prevention. This is a pre experimental research study with one group pre-post test design, children aged 0-24 months as the research subjects. The case group consisted of stunted children (BL/A <-2 SD Z-score), while the control group consisted of normal children according to the $B L / U$ indicator. The number of research subjects for the case and control groups was 40 with mothers of the toddlers as research respondents. The samples were selected using total sampling technique. Data were analyzed using dependent T test and linear regression. The results suggested that at the beginning of the session before provided education about early detection of stunting, mothers with stunting toddlers had lower level of knowledge (73.3\%) than those with normal toddlers (77\%). After provided with education, the knowledge level of mothers with stunted toddlers appreared to be higher (89\%) than those with normal children (87.6\%), with significant increase in each group $(P<0.05)$. It could be concluded that education on stunting detection could significantly improve mothers' knowledge regarding the prevention of stunting in children aged 0-24 months. Providing regular education, both by nutrition workers at the health center and integrated service post (posyandu) cadres, was a necessary to prevent stunting to the maximum.

Keywords: education; early detection; stunting

\section{ABSTRAK}

Stunting merupakan salah satu permasalahan gizi utama yang masih sering ditemukan pada anak balita dan memiliki dampak kesehatan yang serius. Hasil Riskesdas di tahun 2018 menunjukkan prevalensi stunting sebesar 30,8\%, yang artinya 1 dari 3 anak indonesia masih mengalami stunting. Kabupaten Probolinggo menjadi daerah prioritas penanganan stunting yang memiliki prevalensi sebesar 50,2\% pada tahun 2019 berdasarkan laporan Tim Nasional Percepatan Penanggulangan Kemiskinan (TNP2K). Salah satu faktor yang mempengaruhi kejadian stunting secara langsung adalah berat badan lahir rendah (BBLR) sedangkan tingkat pengetahuan ibu terhadap kesehatan menjadi factor tidak langsung yang berpengar; $\mathrm{h}$ pada kondisi pertumbuhan balita. Tujuan dari penelitian ini adalah untuk menganalisis pengaruh pemberian edukasi deteksi dini stunting terhadap pengetahuan ibu tentang pencegahan stunting. Penelitian ini adalah studi pre-eksperimental dengan rancangan pre-post tes dalam satu kelompok, subjek penelitian anak usia 0-24 bulan dengan kelompok kasus adalah anak stunting $(P B / U<-2 S D$ Z-score $)$ dan kelompok kontrol adalah anak yang normal berdasarkan indikator PB/U. Jumlah subjek penelitian untuk kelompok kasus dan kontrol sebanyak 40 dengan ibu balita sebagai responden penelitian. Pemilihan sampel menggunakan teknik total sampling. Analisis data menggunakan uji $T$ dependen dan regresi linier. Hasil penelitian menunjukkan pada awal sesi sebelum diberikan edukasi tentang deteksi dini stunting, ibu dengan balita stunting memiliki pengetahuan lebih rendah $(73,3 \%)$ daripada ibu dengan balita normal (77\%), namun setelah edukasi diberikan rata-rata tingkat pengetahuan ibu dengan balita stunting lebih tinggi (89\%) daripada ibu dengan balita normal (87,6\%) dengan kenaikan pengetahuan yang signifikan pada masing-masing kelompok $(P<0,05)$. Kesimpulan penelitian adalah bahwa edukasi deteksi disi stunting secara signifikan dapat meningkatkan pengetahuan ibu terkait pencegahan stunting pada anak di usia 0-24 bulan. Pemberian edukasi secara berkala baik oleh petugas gizi puskesmas maupun kader posyandu perlu dilakukan sebagai upaya pencegahan stunting secara maksimal.

Kata kunci: edukasi; deteksi dini; stunting

Correspondence: Gadis Meinar Sari, Department of Physiology, Faculty of Medicine, Universitas Airlangga, Surabaya, Indonesia. Jl. Mayjen. Prof. Dr. Moestopo No. 47 Surabaya 60132 Indonesia. E-mail: gadis-ms@fk.unair.ac.id 
pISSN:2355-8393 • eISSN: 2599-056x • doi: 10.20473/fmi.v57i1.23388

- Fol Med Indones. 2020;57:70-75 • Received 24 Nov $2020 \bullet$ Accepted 4 Mar 2021

- Open access under CC-BY-NC-SA license • Available at https://e-journal.unair.ac.id/FMI/

\section{INTRODUCTION}

Stunting is one of the most common nutritional problems in the world and in Indonesia (UNICEF, 2012). Nutritional problems, especially stunting in children, is one of the conditions of malnutrition that has become a major concern in the world, especially in developing countries, as it has impacts on the slow growth of children as well as low level of immunity, intelligence, and productivity (Kurniasih D, Hilmansyah H, Astuti M, Imam S, 2-10). The Ministry of Health (Kemenkes) defines stunting as children under five with a z-score of less than -2SD/(stunted) and less than -3SD (severely stunted) with body length (BL/A) or height (BH/A) according to age compared to the standard WHO-MGRS (Multicentre Growth Reference Study) 2006. The 2013 National Health Research (Riskedas) results show that there has been an increase in the prevalence of stunting from $35.6 \%$ in 2010 to $37.2 \%$ in 2013 , indicating that 1 out of 3 Indonesian children are classified as stunting.

One of the risk factors that influence the incidence of stunting in children under five is a history of low birth weight (LBW) (TNP2K, 2017). As a result, the growth of LBW babies will be disrupted, and if this situation continues with insufficient feeding, frequent infections, and poor health care can cause stunted children. However, the incidence of stunting is also indirectly influenced by socio-economic factors, such as education level, income, and number of household members (RISET KESEHATAN DASAR, 2013).

Several studies have shown that the risks caused by stunting are decreased academic achievement, increased risk of obesity, more susceptibility to noncommunicable diseases and an increased risk of degenerative diseases (Kementrian Kesehatan, 2013). Therefore, stunting is a predictor of poor human resources which in turn will affect the development of the nation's potential (Soetjiningsih, 2012). Based on data from the Central abureay of Statistics (BPS) in 2019, the prevalence of children under five experiencing stunting in 2019 in Indonesia is still quite high, namely $27.7 \%$ with an estimate of 28 out of 100 toddlers experiencing stunting. East Java Province is one of the provinces whose stunting rate is above the national average $(36.81 \%)$, with Probolinggo Regency having a prevalence of $50.2 \%$. (EPPGBM, Dinas Kesehatan Jawa Timur, 2019).
One of the solutions to the problems described above can be done through early detection of stunting in mothers of toddlers. This study aims to analyze the effect of education on maternal knowledge regarding Stunting Prevention in Selogudig Village, Pajarakan District, Probolinggo Regency, East Java Province.

\section{MATERIALS AND METHODS}

This study was a pre experimental study with one group pre-post test design. This study was conducted in Selogudigkulon village, Pajarakan District, Probolinggo Regency-East Java. The study location was chosen purposively based on the data showing that the prevalence of stunting in Selogudigkulon Village was included in the top 100 (TNP2K 2017). The population in this study were all mothers with toddlers aged 0-24 months with a sample of 20 mothers with stunted toddlers and 20 mothers with normal toddlers selected based on total sampling. The intervention was carried out by providing education on early detection of stunting through lectures and question-and-answer sessions.

Data collection was carried out using a self-assessment questionnaire with the assistance of 2 (two) public health graduates. The knowledge questionnaire on stunting prevention contained fifteen multiple choice questions. The questionnaire was filled twice (before and after the stunting) education intervention was given. The interventions were given in the form of lectures related to stunting, breastfeeding, and clean and healthy living behavior (PHBS) followed by an interactive question and answer session as well as exposure to early detection of stunting using a stunting detection blanket measuring device. The intervention lasted 90 minutes. Data processing was performed using SPSS 22 IBM Statistics with statistical analysis of dependent $\mathrm{T}$ test (? $<0.05)$ to see an increase in knowledge.

\section{RESULTS}

\section{Respondent characteristics}

Selogudigkulon Village is located in Pajarakan District, Probolinggo Regency, East Java Province, Indonesia. This village is located in the south about 12 kilometers from the capital city of Probolinggo Regency. Based on observations, public integrated service post (posyandu) 
is conducted once a month with regular nutritionist visits at the time the posyandu is scheduled, but along with the COVID-19 pandemic conditions, posyandu is conducted through direct visits by local cadres. The characteristics of the 40 respondents included maternal age, maternal education, maternal occupation, family income, age at marriage and maternal height.

In this study, the mothers' age was categorized into 2, namely less than 20 years old or over 35 years old and between 20 to 35 years. The characteristics of respondents were presented in Table 1 . The results showed that most of the respondents were between the ages of 20-35 years old (65\%). A person's productive period was a period where someone easily accepted the learning process and the development of their intellectual power was in the age range of 20-35 years (Rahmawati 2012). A person at the age of 20-35 years was considered to have had enough experience and a growing way of thinking as well as the knowledge on how to provide good complementary feeding to their babies (Sediaoetama 2010).

Furthermore, in the category of education level, it was found that the majority of mothers' education levels were at non-tertiary institutions (non-college) (95\%). The level of family education, especially the mothers' education, could be a factor that affected the nutritional status of children and families. Children with malnutrition conditions usually occured due to the lack of parents' attention to children's nutrition; one of which was influenced by the mother's low level of knowledge on nutrition. Mothers' formal education affected maternal nutritional knowledge which in turns affected health behavior to care more about the nutritional status of children and families (Sediaoetama 2010).

Most of the respondents in the Pajarakan Health Center work area became housewives as many as 36 respondents $(90 \%)$ (Table 1). According to other studies, mothers who do not work will pay more attention to the quality and quantity of food that will be consumed by their children. Mothers who did not work have more time to care for their children, although other factors such as knowledge and parenting also needed to be considered (Bishwakarma \& Vanneman 2011). In addition, the fact that the mothers did not work also had an effect on their families' monthly income.

The income category was adjusted to the Regional Minimum Wage for Work (UMK) in Probolinggo as many as IDR 2,319,796.75. Of all respondents, 90\% were families who had an income below the UMK. Economic status affected the purchasing power of parents in getting food with high nutritional value. Some studies suggested that income was a factor that greatly affected the ability to choose the quality and quantity of food (Prendergast \& Humphrey 2014). The low economic status of a family could negatively impact the children's growth, such as the likelihood of the child becoming thin and short (UNS/SCN 2013).

Table 1. Social demographic characteristics of respondents participating in early detection of stunting education

\begin{tabular}{|c|c|c|}
\hline \multirow{2}{*}{ Characteristics } & \multicolumn{2}{|c|}{$\begin{array}{c}\text { Number of } \\
\text { Respondents }(n=40)\end{array}$} \\
\hline & $\mathrm{n}$ & $\%$ \\
\hline \multicolumn{3}{|l|}{ Respondents' Age } \\
\hline$<20$ or $>35$ years old & 14 & 35 \\
\hline 20-35 years old & 26 & 65 \\
\hline \multicolumn{3}{|l|}{ Respondents' Level of Education } \\
\hline College & 2 & 5 \\
\hline Non-College & 38 & 95 \\
\hline \multicolumn{3}{|l|}{ Occupation } \\
\hline Teacher & 1 & 2.5 \\
\hline Laborer & 1 & 2.5 \\
\hline Private Company Employee & 1 & 2.5 \\
\hline Village Officials & 1 & 2.5 \\
\hline Not Working/Housewives & 36 & 90 \\
\hline \multicolumn{3}{|l|}{ Family Income (UMK 2020) } \\
\hline$<$ IDR 2,319,796.75 & 36 & 90 \\
\hline$\geq$ IDR $2,319,796.75$ & 4 & 10 \\
\hline \multicolumn{3}{|l|}{ Age at Marriage } \\
\hline Teenager $(<=19)$ & 14 & 35 \\
\hline Normal (> 19) & 26 & 65 \\
\hline \multicolumn{3}{|l|}{ Exclusive Breastfeeding } \\
\hline Yes & 40 & 100 \\
\hline No & 0 & 0 \\
\hline \multicolumn{3}{|l|}{ Respondents' Body Height } \\
\hline Short $(<150)$ & 20 & 50 \\
\hline Not Short $(>=150)$ & 20 & 50 \\
\hline
\end{tabular}

In Table 1, the age of the respondents at marriage indirectly related to the age of the mothers having their first pregnancy. Of all respondents in this study, 65\% were married at normal ages (>19 years old), while the remaining $35 \%$ were married at ?19 years old. A mother who was pregnant in her teenage years is still in her infancy, thus causing the risk of seizure of nutrients between the fetus and the mother's metabolism itself. This situation becoame worse when the mother's nutritional intake was inadequate, causing the fetus to experience growth restriction. This increased the risk of the fetus being born with low birth weight or premature birth, both of which were the factors in the occurrence of stunting in toddlers (WHO 2011).

Based on the respondents' body height data, it was found that $50 \%$ of the respondents were in the short category and the other $50 \%$ were in the not short category. In this study, the characteristics of the 
mothers' heights were divided into 2 , namely short with body height of $<150 \mathrm{~cm}$ and not short with body height of ? $150 \mathrm{~cm}$. The height of a mother also affected the growth and development of the child. This was because the blood flow of the uterus and the growth of the uterus, placenta and fetus in short pregnant women was limited, causing the baby to be boen with low weight. Thus, it was necessary to make improvements to the occurrence of fetal growth slowdown or retardation known as IUGR (Intra Uterine Growth Retardation) and low birth weight (LBW) (Andriani et al 2017). This incident would also take place in the next generation. The problem of stunting between generations was unavoidbale unless there was an improvement in nutrition and adequate health services at that time.

Short mothers did not always have short children (stunting) even though there was a tendency for short mothers to give birth to stunted children. If the parenting, especially the diet was good and included proper complementary feeding, the child would grow up healthy and optimally. The promotion of exclusive breastfeeding for six month-long followed by complementary feeding and breastfeeding was UNICEF's program outline. This was important as an effort to prevent overweight and stunting in infants and toddlers (Bishwakarma \& Vanneman 2011). All (100\%) respondents in the working area of the Pajarakan Health Center gave exclusive breastfeeding to babies and toddlers. This is a good first step in parenting for growing children and toddlers.

\section{Respondents' Level of Knowledge}

Out of the 40, two groups were divided with 20 participants in each group. Mothers with stunting toddlers had lower level knowledge $(73.3 \%)$ than those with normal toddlers $(77 \%)$. However, after education was provided, the mean level of knowledge of mothers with stunting toddlers appeared to be higher $(89 \%)$ than those with normal toddlers $(87.6 \%)$ with a significant increase in knowledge on each group $(\mathrm{P}<0.05)$.

Table 2. Mean values of pre and post test in session 1 (group of mothers with stunting toddlers and session 2 (mothers with normal toddlers)

\begin{tabular}{lllll}
\hline & N & Mean & SD & SE \\
\hline SESSION 1 PRE & 20 & 73.333 & 14.018 & 3.134 \\
SESSION 1 POST & 20 & 89.000 & 7.578 & 1.695 \\
SESSION 2 PRE & 20 & 77.000 & 16.959 & 3.792 \\
SESSION 2 POST & 20 & 87.667 & 13.206 & 2.953
\end{tabular}

Table 3. Statistical analysis of increased knowledge in the pre and post test groups of mothers with stunting toddlers and those with normal toddlers

\begin{tabular}{llc}
\hline \multicolumn{1}{c}{ t } & df & $\mathbf{p}$ \\
\hline SESI 1 PRE - SESI 1 POST -5.887 & 19 & $1.142 \mathrm{e}-5$ \\
SESI 2 PRE - SESI 2 POST & -3.47019 & 0.003 \\
\hline
\end{tabular}

Note. Student's t-test.

In the carried out paired $\mathrm{T}$ test, in tables 2 and 3 , it is found that the average level of knowledge in mothers with normal toddlers and mothers with stunted toddlers has increased significantly after education, indicated by a $p$ value of $<0.05$. This suggests that the influence exerted by this study was a positive influence for respondents with an increase in understanding and knowledge. The results of this study are in line with Andriani's research in 2017 conducted in the working area of Public Health Center (Puskesmas) Puluwatu, Kendari City, suggesting that there was a significant difference in knowledge before and after the mothers being given the Mother Smart Grounding (MSG) program in preventing stunting (Andriani et al 2017). There is also another research on measuring the nutritional status of toddlers as an effort to prevent stunting conducted in the Randugunting Hamlet, Sleman. The study revealed that there was a difference of means between the values before being given training and the values after being given training, proving the provision of education, training and simulations to be effective in increasing respondents' knowledge.

In a research on monitoring the nutritional status of toddlers for Posyandu cadres by Zaki et al (2018), the results of the activities evaluation showed that there was an increase in knowledge and skills scores before and after being given training and monitoring on the nutritional status of toddlers to cadres. The improvement can be seen from the participants' ability to correctly weigh standing toddlers, measure the weight of babies of less than two years old, measure the height of toddlers, and fill out the Growth Card (KMS). Furthermore, the training of health cadres in early detection of nutritional disorders also showed an increase in knowledge and skills. The impact is that the health cadres have shown improvements in making referrals for nutritional disorders for children under five, while mentoring by cadres has a positive impact on nutrition health services for children under five (Hati \& Pratiwi 2019).

The nutritional health of infants and toddlers is highly important for parents to pay attention. A healthy child is 
not susceptible to disease, including infectious diseases which are dominant in nutritional problems. This is because a healthy child has a good immune system. The immune system changes according to the nutritional health of the child's body. If a child's nutritional health is good, his immune system will increase. Conversely, if the nutritional health condition decreases, then his immune system will decrease (Kosasih et al 2012). Parental education is one of the important factors in children's development since adequate education can affect the behavior of stimulating children's growth and development by parents. The lack of stimulation of children can cause growth and development disorders of children and even persistent disorders (Soetjiningsih \& Ranuh 2014).

Table 4. Analysis of the respondent's level of knowledge on each question item (scale 0-100)

\begin{tabular}{|c|c|c|c|c|c|}
\hline \multirow{3}{*}{ No } & \multirow{3}{*}{ Question Item } & \multicolumn{4}{|c|}{ Number of Correct Answer n (\%) } \\
\hline & & \multicolumn{2}{|c|}{ Session 1} & \multirow{2}{*}{\multicolumn{2}{|c|}{$\frac{\text { Session } 2}{\text { Post-test }}$}} \\
\hline & & Pre-test & Post-test & & \\
\hline 1 & What is the other name for stunting? & $16(80)$ & $19(95)$ & $18(90)$ & $19(95)$ \\
\hline 2 & $\begin{array}{l}\text { Stunting occurs due to the lack of nutritions in a long term, } \\
\text { namely? }\end{array}$ & $12(60)$ & $19(95)$ & $13(65)$ & $17(85)$ \\
\hline 3 & What are the long-term impacts of stunting? & $13(65)$ & $12(60)$ & $18(90)$ & $18(90)$ \\
\hline 4 & $\begin{array}{l}\text { Which of these following statements are not included as the } \\
\text { stunting prevention? }\end{array}$ & $11(55)$ & $11(55)$ & $13(65)$ & $11(55)$ \\
\hline 5 & $\begin{array}{l}\text { Which of these followings statements are included as the simple } \\
\text { steps to prevent stunting toddlers? }\end{array}$ & $17(85)$ & $20(100)$ & $18(90)$ & $19(95)$ \\
\hline 6 & Until what age should breastfeed be given to an infant? & $19(95)$ & $16(80)$ & $17(85)$ & $14(70)$ \\
\hline 7 & What are the benefits of breastfeeding? & $8(40)$ & $16(80)$ & $11(55)$ & $16(80)$ \\
\hline 8 & What is the correct duration of breastfeeding? & $6(20)$ & $20(100)$ & $12(60)$ & 18 \\
\hline 9 & $\begin{array}{l}\text { Is it allowed to give a banana to infants of }<6 \text { months to help them } \\
\text { feel full quicker? }\end{array}$ & $17(85)$ & $20(100)$ & $15(75)$ & $19(95)$ \\
\hline 10 & What do you do if your nipples blister or bleed? & $18(90)$ & $20(100)$ & $18(90)$ & $19(95)$ \\
\hline 11 & What is Clean and Healthy Living Behavior (PHBS)? & $13(65)$ & $20(100)$ & 10 & $20(100)$ \\
\hline 12 & Which of the following are PHBS in a household? & $20(100)$ & $20(100)$ & $18(90)$ & $20(100)$ \\
\hline 13 & $\begin{array}{l}\text { Which of the following are not the requirements for a healthy } \\
\text { toilet? }\end{array}$ & $14(70)$ & $14(70)$ & $11(55)$ & $17(85)$ \\
\hline 14 & Is daily consumption of fruit and vegetable a part of PHBS? & $18(90)$ & $20(100)$ & $20(100)$ & $20(100)$ \\
\hline 15 & Why should you implement PHBS? & $20(100)$ & $20(100)$ & $19(95)$ & $20(100)$ \\
\hline
\end{tabular}

As seen in table 4 , it is found that the level of changes in the knowledge of the two groups has increased. The highest score on the pre-test in the first session group, namely mothers with stunted toddlers, was 100 points and the lowest was 20 points. Meanwhile, there is a high increase in the post-test score with 55 being the lowest score. Changes in the level of knowledge also occurred in the second group, namely mothers with normal toddlers, with the lowest value being greater than those in the first group. In the pre-test, 50 was the lowest score and one respondent obtained 100 points as the highest score.

In the second group's post-test score, the lowest score was 70 points and the highest was still 100 points, but the number of respondents who obtained it increased by 4 people. The correct answers most commonly found in both groups were on the topic of questions about breastfeeding, PHBS, and followed by stunting in the last position. This indicates that the respondents' understanding of stunting was still less than the topics of breastfeeding and PHBS. Based on this, it could be seen that the level of knowledge of mothers with normal children under five was better than mothers with stunting in the pre-test and post-test scores with the pretest mean value of the first group being $14.8 \pm 75$ and the second group $15.4 \pm 80$. In the post test results, the mean of the first and second groups had the same value, such as $17.8 \pm 95$

\section{CONCLUSION}

This study showed that providing education on early detection of stunting could significantly increase 
mothers' knowledge regarding the prevention of stunting in children aged 0-24 months. The provision of regular nutrition education by nutritional workers at the health center and posyandu cadres was necessary as an effort to prevent stunting.

\section{REFERENCES}

Andriani WOS, Rezal F, Nurzalmariah WDST (2017). Perbedaan p, sikap, dan motivasi ibu sesudah diberikan program mother smart grounding (MSG) dalam pencegahan stunting. Jurnal Ilmiah Mahasiswa Kesehatan Masyarakat, 2, 250-731.

Bishwakarma R, Vanneman RD (2011). Spatial inequality in child nutrition: Implications of regional context and individual/household composition. Dissertation, Maryland University, Coll. Park, p. 119140.

Budiman, Riyanto A (2013). Kapita selekta kuesioner pengetahuan dan sikap dalam penelitian kesehatan. Surabaya: Salemba Medika.

Chamilia D, Nindya TS (2017). Hubungan riwayat penyakit diare dan praktik higiene dengan kejadian pada balita usia 24-59 bulan di wilayah kerja Puskesmas Simolawang, Surabaya. Amerta Nutr, 1, 243-251.

Crookston B, Penny ME, Alder SC, Dickerson TT, Merrill RM, Stanford JB, Porucznik CA, Dearden KA (2010). Children who recover from early stunting and children who are not stunted demostrate similar levels of cognition. J Nutr, 140, 1996-2001. doi: 10.3945/jn.109.118927.

EPPGBM, East Java Health Department, 2019

Hati FS, Pratiwi AM (2019). The effect of education giving on the parent's behavior about growth stimulation in children with stunting. NurseLine Journal, 4, 12-20.

Ministry of Health (2013). Makanan sehat untuk bayo. Accessed on depkes.go.id
Kurniasih D, Hilmansyah H, Astuti M, Imam S (2010). Sehat \& bugar berkat gizi seimbang. Jakarta: Kompas Gramedia.

Kosasih CE, Isabella C, Sriati A (2012). Upaya peningkatan gizi balita melalui pelatihan kader kesehatan. Jurnal Media Karya Kesehatan, 1, 90-100.

Prendergast AJ, Humphrey JH (2014). The stunting syndrome in developing countries. Paediatr. Int. Child Health, 34, 250-265.

Rahmawati A, Bahar B, Salam A (2012). Pengaruh kecerdasan intelektual, kecerdasan emosi, dan kecerdasan spiritual terhadap kinerja karyawan. Majalah Ilmiah Informatika, 3, 1-20.

Basic Health Research, (2013). Results of Basic Health Research. Jakarta: Badan Penelitian dan Pengembangan Kesehatan Kementerian Kesehatan RI.

Sediaoetama, A. . Ilmu gizi untuk mahasiswa dan profesi. Jakarta: PT.Dian Rakyat.

Soetjiningsih IG (2012). Tumbuh kembang anak. Jakarta: Buku Kedokteran EGC.

Soetjiningsih IG, Ranuh NG (2014). Tumbuh kembang Anak edisi 2. Jakarta: EGC.

TNP2K. 100 Kabupaten/ Kota Prioritas Untuk Intervensi Anak Kerdil (Stunting). 1st ed. Jakarta: Tim Nasional Percepatan Penanggulangan Kemiskinan; 2017.

Unicef. Gizi Ibu \& Anak. Unicef Indonesia. 2012;1-6.

UNICEF (2013). Improving child nutrition: The achievable imperative for global progress.

UNS/SCN (2013). Maternal nutrition and the intergenerational cycle of growth failure: The sixth report on the world nutrition situation.

WHO (2011). Guidelines for preventing early pregnancy and poor reproductive outcome in adolescents in developing countries.

Zaki I, Farida F, Sari HP (2018). Peningkatan kapasitas kader posyandu melalui pelatihan pemantauan status gizi balita. Jurnal Pengabdian Kepada Masyarakat, 3, 169-177 